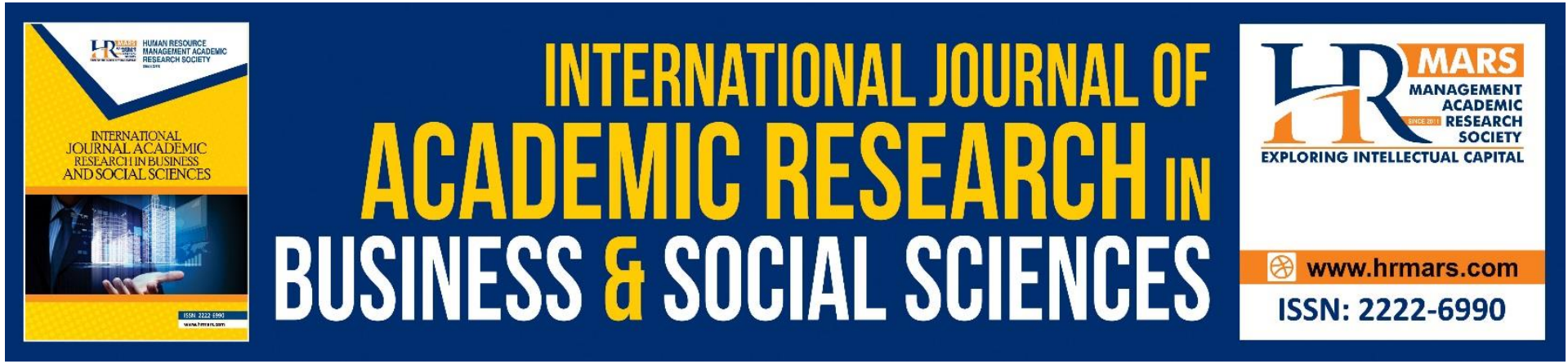

\title{
Humanity Values and the Challenges of Maintaining Ethnic Relations According to the Islamic Perspective In Industrial Revolution 4.0 (IR4.0)
}

Che Sulaila Che Harun, Wan Zulkifli Wan Hassan, Mashitoh Yaacob

To Link this Article: http://dx.doi.org/10.6007/IJARBSS/v11-i8/10766

DOI:10.6007/IJARBSS/v11-i8/10766

Received: 02 June 2021, Revised: 28 June 2021, Accepted: 20 July 2021

Published Online: 15 August 2021

In-Text Citation: (Harun et al., 2021)

To Cite this Article: Harun, C. S. C., Hassan, W. Z. W., \& Yaacob, M. (2021). Humanity Values and the Challenges of Maintaining Ethnic Relations According to the Islamic Perspective In Industrial Revolution 4.0 (IR4.0). International Journal of Academic Research in Business and Social Sciences, 11(8), 656-666.

Copyright: @ 2021 The Author(s)

Published by Human Resource Management Academic Research Society (www.hrmars.com)

This article is published under the Creative Commons Attribution (CC BY 4.0) license. Anyone may reproduce, distribute, translate and create derivative works of this article (for both commercial and non-commercial purposes), subject to full attribution to the original publication and authors. The full terms of this license may be seen

at: $\underline{\text { http://creativecommons.org/licences/by/4.0/legalcode }}$

Vol. 11, No. 8, 2021, Pg. 656 - 666

Full Terms \& Conditions of access and use can be found at http://hrmars.com/index.php/pages/detail/publication-ethics 


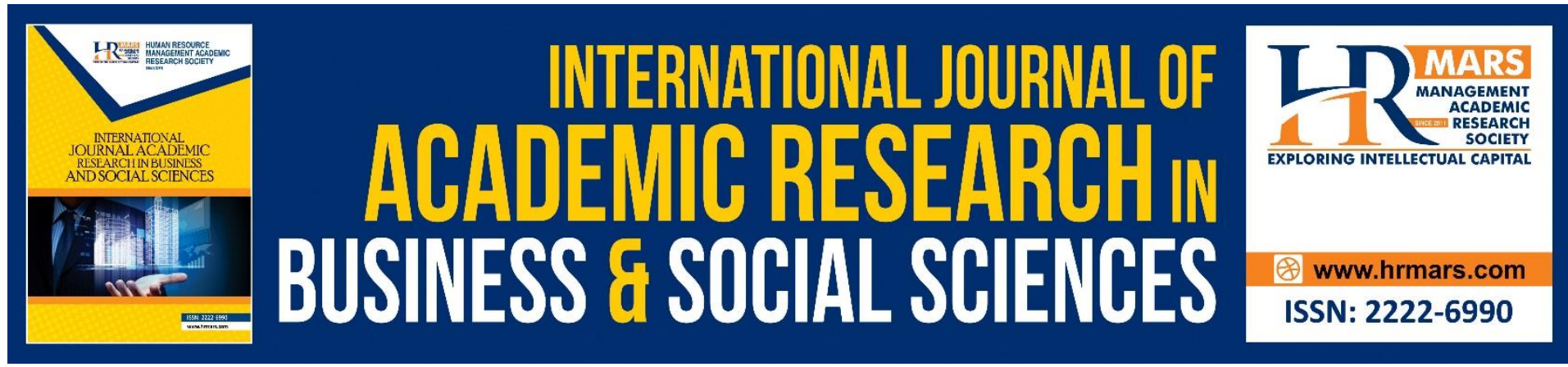

\title{
Humanity Values and the Challenges of Maintaining Ethnic Relations According to the Islamic Perspective In Industrial Revolution $\mathbf{4 . 0}$ (IR4.0)
}

\author{
Che Sulaila Che Harun ${ }^{1}$, Wan Zulkifli Wan Hassan ${ }^{1,2}$, Mashitoh \\ Yaacob ${ }^{1,2}$ \\ ${ }^{1}$ Institut Islam Hadhari, Universiti Kebangsaan Malaysia, ${ }^{2}$ Pusat Pengajian Citra Universiti, \\ Universiti Kebangsaan Malaysia
}

\begin{abstract}
Human values play an important role in shaping a person's character, especially in today's increasingly challenging era. It can be obtained through an understanding of religion which is a major branch in the formation of one's human values. In the era of the Industrial Revolution 4.0, various threats arose among some societies regarding the appreciation of human values because they so glorify science and technology that they challenge the norms of harmonious society. This situation if left unchecked will definitely have a negative impact, especially on ethnic unity in the country. Adherence to human values is an important aspect to strengthen development agents in a country without being swept away by the currents of progress. The good elements that need to be applied in society is to appreciate the high values of humanity as in ethnic relations according to Islam. Thus, the objectives of this study were to identify: (a) The Challenges of the Industrial Revolution 4.0 in terms of human values; and (b) The application of inter-ethnic human values according to Islam in maintaining ethnic harmony in Malaysia. This discussion uses a descriptive qualitative method i.e. literature review. The study found: (a) the relationship between religion, culture and ethnicity is not a natural process and is a challenge in the technological development of the Industrial Revolution 4.0; (b) The understanding and practice of ethnic relations according to Islam is able to cultivate society to instill high human values in the self. This discussion is a pioneering view to produce a study of the development of human values in the Industrial Revolution 4.0
\end{abstract}

Keywords: Humanity Values, Industrial Revolution 4.0, Ethnic Relations

\section{IR4.0 Challenges in the Context of Humanity Values}

Humanity values refer to the measurement of quality of a human. Meanwhile, humans refer to the intelligence, also the mental and physical abilities following his or her natural circumstances. IR4.0 is based on the digital platform endeavored to substitute for the roles and responsibilities of humans. From the humanity standpoint, globalization in this industry has its effect on the use of humans. In Islam, humans are the caliphs of Allah SWT. They not 
only take the tasks of managing and administering the universe, but they also possess their soul, qalb, nafs, mind and body, where all of which have to be in equal balance.

In reference to the robot Sophia for instance, it has taken over the roles played by humans that it has violated human rights (Van Badham, 2017). Human-robot interactions will never fulfill the universal values and norms, despite the marriage or union between the robot Yingying and its own creator from China (Haas, 2017)- it only portrays human intelligence and it is not a natural process of life. These robots are merely treated as sex dolls when they are chosen as life partners and nurses when they care for the elderly in Japan (Hurst, 2018). Thus, a model of humanity values needs to be developed so that technological growth in IR4.0 does not neglect human's natural processes.

\section{The Challenges of the Growth of the Information Technology}

Globalization has entered a new era named Industrial Revolution 4.0. (RP4.0). In Malaysia RP4.0 or known as Industry 4.0 uses various convergence of technologies in an industrial system. RP4.0 has a more realistic vision encompassing loT, Industrial Internet, Smart Manufacturing and Cloud based Manufacturing (Vaidyaa et al., 2018). The current trend for manufacturing technology involves things such as automation, loT and cyber-physical systems. In this development, loT is seen as the best platform to leverage various fields of technology to give an added value to a wide range of industries in the country. It not only leaves an impact to the transformation of the entire system in the country, such as company, industry and society, but it also involves an international system network.

Thus, the key to facing IR4.0 is not just about technological growth, but other aspects also have to be considered, in terms of the values that can be held on by the members of the society so that the negative impacts of the IR4.0 technology can be properly addressed. These values are hoped to become a neutraliser, so that the society can also get involved in IR4.0 activities in a more systematic way and in keeping with the demands of the values of the society (Abdul Khalil et al., 2020).

The societal values are important as the point of reference in addressing issues brought upon by the development of IR4.0 such as cyber-syndrome, cyber crime, hackers, plagiarism in education, cyber information screening and so on. Thus, this study will look into several changes that have happened to the roles of humans, the invention of the humanoid and the occupational sector affected by the surge of the IR4.0 technology.

\section{Challenges of Relational Network}

The changes in the lifestyle that are taking place in the world today have made many people question the true nature of IR4.0. This technological growth often gives a great impact to culture, values, religion, way of life, way of thinking and so on. The leading IR4.0 technology namely the Internet of Things (IoT) is where humans and objects are prepared with exclusive identities and the capability to transfer the information through a network without needing the human to human interaction and instead using human to computer interaction (Burange and Misalkar, 2015). loT is the knowledge development that optimises life based on smart sensor and equipment that collaborate with the internet network (Keoh et al., 2014). It also connects things with the Internet infrastructure (wire or wireless) and uses the relationship to monitor or control the equipment long distance. This works by connecting billions of individuals in a web, where business and organisation's efficacy will increase drastically and the natural environment will be established through a better asset management. This leads 
to the industrial era for fields like robotic and $\mathrm{Al}$, nano technology, quantum computing, genetic engineering, bio technology and 3D printing (Schwab, 2016; Hermann et al., 2016).

The use of the information technology and the communication to the industry become integral when IOT becomes the primary tool in IR4.0, for example through the use of navigation applications like Waze or Google Maps that are equipped with guide on route and trip information, high-impact technology such as $4 \mathrm{G}$ and $5 \mathrm{G}$ also Cloud Computing, digital economy, Al, big data, robotic, blockchain, 3D printing, Big Data, space technology, CCTV safety system and so on (Vaidyaa et al., 2018). Mastery in coding is also very important to enable easy interaction with the technology. Facebook for example, is the product of a student who had evolved the boundaries, by integrating high level languages and the Graphical User Interface (GUI), and even Netflix, Twitter are also the results of the use of code (Wood, et.al. 2017). Pieces of information that emerge in stages and in various forms have exponentially grown to the point that they become overloaded (Wood et al., 2017; Schwab, 2016).

Social interactions become unlimited due to the easy access of the Internet and the technology. Klaus Schwab (2016) predicted that IR4.0 will leave a profound impact to the national and international security. Through the digital facility access, it is undeniable that the moral, attitude and behaviour of the society will take a new turn. Amid the technological facilities offered in IR4.0, some negative effects and threats are also exposed to human identity such as a sense of privacy, the notion of ownership, the consumption pattern, the time allocated for work and rest, the ways of building career, also skill building and development (Schwab, 2016).

\section{Challenges of Retaining Ethnic Relations through the Islamic Perspective}

Ethnic refers to a group of people that practises an almost uniform culture, including customs, clothes, languages and economic activities. Ethnic diversity in a society should not stand in the way of racial unity (Shamsul, 2012). The society refers to a group of people that live together in a place in a certain arrangement and way, where they are mutually dependent and are in need of one another. These individuals will have their families, whereas the families will form small groups known as the members of the society. The pluralistic society means the diversity that comes naturally so with the collaboration and understanding of these multiple ethnic groups, then there will be peace and harmony in the country.

In Malaysia, the pluralistic society comprises of various ethnicities and they have formed a union. The ethnic groups in Malaysia are composed of Malays, Chinese, Indians and other ethnic groups. They live together and unite especially in social, economy and political aspects. The Malaysian environment is full of multiple races, religions and cultures and yet, still able to live in peace and harmony. Such a union is known as plurality. In Islam, plurality refers to the unity in the diversity or the unity of multiple races and ethnic groups.

The emergence of the modern digital technology in the growth of IR4.0 has reduced the use of human energy or manual labour by transforming the operation to the automatic system through the computer system or the format that can be read by the computer (Hermann et al., 2016). This digital technology has created a virtual space to perform all types of activity and get the information. From the communication perspective, it shows the 
efficacy in sending information, and it is more dynamic without spatial and time-based obstacles. Digital tools that are often used based on the Internet can connect humans through the social media like Facebook, YouTube, Instagram and others and this has facilitated human to human interactions (Wood et al., 2017).

This has formed a community that leads a new lifestyle, characterised by post-modern society, evident in extreme secularism, individuals going against the grain, human freedom, human rights movement, and the right to challenge the cultural and religious norms (Vitz, 2016; Kim \& Heo, 2018; Wang \& Siau, 2019; Pratama, 2019). In Islam, humans are granted by Allah an ideal physical form and structure, whereby in this world they undertake the task of His Caliphs, on this earth. Allah has decreed in the Al-Quran which means:

And remember when We say this to the angels, indeed I create humans as Caliphs on Earth

(Al-Baqarah:30)

This directly points at humanity values as the basis of ethnic relations, but Islam itself forbids its people or society to have assabiyah or extreme racism to avoid feuds and arguments among the races. Human's dependency on the technology in IR4.0 shows a form of individual interaction towards the digital tool to the point that there is a missing human touch, and it diminishes along with the interactions with the society. Humans appear to be tightly bound to technology that the mental functions slow down (Ali et. al., 2017) so much so that it creates soulless humans, or people who lost his sense of humanity. Humans and humanity will be affected when their development is disrupted with the emergence of the transhumanism concept or the tendency to act like a machine or more accurately, functioning as if they are lifeless machines, that work non-stop at certain speed, agility and intelligence. (Badhrulhisham et. al., 2019).

The involvement of the technology adopted in IR4.0, for example Artificial Intelligence (AI) helps increase human labour's productivity, while Blockchain will help open the access to banking, and the robots will aid in the coordination of the Return of Investment (ROI) (Wood et. al., 2017). Industry 4.0 will continue to develop new technology aiming at gaining profit after profit and denying human roles. What is even more alarming is that this technology is able to challenge the cultural and religious norms in the society. The use of this borderless technology also leaves a negative impact to humans in terms of slowing down their mental function as they are very dependent on the technology (Ali et. al., 2017).

\section{Application of Ethnic Relations According to Islamic Perspective in Facing Ir4.0 Challenges}

Prophet Muhammad SAW was sent to bring about grace and blessing to Islam, while the Madinah Charter was seen as proof that Islam recognizes ethnic diversity. According to Muhammad (1987), ethnic relations are societal relations structured by Islam among Muslims and non-Muslims, which is built on the basis of goodness, glory, justice, discussions, and aid and assistance as well as prevention of evil that could tear apart a community. Respect towards humans is by respecting the soul of the person itself without taking into account religion and ethnicity. Islam constantly establishes relationships between its people and nonMuslims based on neat and solid principles, which encompasses tolerance, justice, charity, 
and compassion, which have not been found in the history of humanity before Islam (Yusuf, 1989). Therefore, Muslims are demanded to perform charity and implement justice to all humanity even if the other person is not a Muslim, as long as they do no oppose to Islam. Ethnic relations must be centered on the comprehensive and all-encompassing theories of Islamic teachings where the Quran has explained the wisdom behind multi-ethnic mankind.

Malaysia is a country with a heterogeneous society comprising of various ethnicities, where every ethnic has its own religion, culture, language, and their own customs and traditions. Among the ethnics found in Malaysia include Malays, Chinese, Indians, Kadazans, and Bajau among others. The forming of a heterogeneous society in Malaysia is due to the rapid expansion of the tin ore and rubber industry around the $19^{\text {th }}$ century. Even though these ethnicities co-exist in the same country and under one political system, however they each retain their own traditions, identity, customs, culture, and religion.

The heterogeneity of the Malaysian society with this combination of races must be taken into consideration when outlining the methods and crusade of Islam. The heterogeneity of the Malaysian population does not stand in the way of implementing Islam fully. In fact, the unification among the numerous races, religions, people and ethnicity in this country is through emulating the leadership style applied by the Prophet Muhammad S.A.W when ruling the Islamic state of Madinah.

In tandem with the expansion of Internet technology, the humanistic way of life has also undergone profuse changes (Ayub et. al, 2014). The term Gen-Z is a generation that grew up with the sophistication of IR4.0 technology with digital ability, trailblazing smart and sophisticated intelligence Gen- $Z$ is a computerized generation; they possess specific understanding and articulation abilities. Gen-Z are able to exploit outstanding assets from the Internet and create computerized innovations to become something imaginative, inventive, and expressive (Majidah et. al., 2019).

The rapidity of technology in IR4.0 causes children to grow in an environment that is inundated with ease of access to borderless information (Miftachul et al., 2017). They experience striking lifestyle changes following the influence of modern technology in their everyday life. The development of children up to their teenage years is now highly influenced by socialist agents such as media. In fact, media plays a role in education, behaviours, and the attitudes of the children (Stapa et. al., 2012). Despite the good that technological sophistication brings about, humans will inevitably face risks such as cyber-syndrome, denial of reality, and so forth (Kim \& Heo, 2018).

This matter has contributed towards the challenges that the various ethnicities who live in the country to understand one another, unity, assisting one another, and tolerance among each other. In the al-Quran, it is shown that Allah S.W.T commanded His servants to stand with each other or with other races. Allah S.W.T despises those to harbor feelings of jealousy towards other races. The decree of Allah S.W.T, which means:

O mankind, indeed We have created you from male and female and made your people and tribes that you may know one another. Indeed, the most noble of you in the sight of Allah is the most righteous ${ }^{1}$ of you. Indeed, Allah is Knowing and Aware. 
As a religion that is syumul, Islam recognizes the existence of heterogeneous societies as a social fact as determined by Allah S.W.T. The racial diversity that exists should not be assumed as an element of division. Islam promotes the concept of brotherhood without looking at race and descent, skin colour, one's social standing, or even geographical boundaries. Allah S.W.T has reminded humans all over to embrace a sense of understanding among each other, respect, as well as living in peace and harmony. The assessment of a person's dignity is based on the concept of taqwa, which is faith and constantly performing duties as decreed by Allah S.W.T.

\section{Ethnic Relations Elements According t Islamic Perspective}

In social life, there is a need to apply good ethnic relations such as affection, communication, visiting one another, caring for one another, mutual respect, and to respect the practices of other races. In Islam, there are several important elements that should be practiced in the community in order to maintain good and harmonious relationships between ethnicities.

\section{Mutual cooperation (Ta'awun)}

In Islam, the concept of mutual cooperation between humans is highly emphasized regardless of race of religion, so long it does not lead to disobedience and go against Islamic akidah. Islam even encourages universal cooperation in various fields and sciences in order to further the nation's progress and harmony (Norafifah, 2014). The cooperation provided is not only within the race and religion but also without discriminating other races and religions, such as collaborations in the form of energy, wealth, time, and so forth. Therefore, with the presence of harmonious social relations coupled with attitudes such as assisting one another, cooperation, and mutual support shown by the various races and religion, this will then create an atmosphere of unity and progress in a multicultural nation such as Malaysia.

\section{Introduction (Ta'ruf)}

Ta'ruf, or introduction, means to delve into a person with the purpose to create feelings of affection. This introduction is not only on the name and the address, but to also learn their background, standing, personality, lifestyle, culture, and ethnic origins among others. This situation may occur if the community lives in an atmosphere that is friendly and with a need to be acquainted with each other. Allah S.W.T loves those who often show love between each other. He decreed,

O mankind, indeed We have created you from male and female and made your people and tribes that you may know one another. Indeed, the most noble of you in the sight of Allah is the most righteous ${ }^{1}$ of you. Indeed, Allah is Knowing and Aware.

Allah S.W.T created mankind in innumerable skin colours, races, nations, and ancestry so that they may be acquainted with each other and do good in a harmonious and peaceful lifestyle atmosphere without any enmity. This is as any enmity will only cause loss and will not benefit any parties (Norafifah, 2014). Therefore, ta'ruf is an important element in a Malaysian lifestyle that comprises of multiple races in order to achieve a united and harmonious nation. 


\section{Affection (Mahabbah)}

Allah S.W.T gifts every human being with an affectionate attitude no matter their race, religion, or ethnicity. An affectionate attitude is one of the human values that must be nurtured and sown in every member of the community. This is so it may enable a friendly and compassionate relationship between a community that comprises of different ethnicities and religions. Once the heart begins to care, therefore it will abstain from feelings of hate, jealousy, and enmity among one another (Norafifah, 2014).

The care element will be enhanced when the foundation of affection is appreciated. In fact in Islam, the feeling of putting others ahead of oneself is the highest form of affection; this is also known as empathy, which is the ability of the individual to delve deep into another person's feelings. Therefore, when this feeling of affection exists within the individual, they would no longer be purely selfish but will strive to make an effort to think about the hardships and challenges others may face without thinking about their ethnicities, race, or religion. This shows Islam as a beautiful religion and places emphasis on the humanity aspect among humankind.

\section{Mutual understanding (Tafahum)}

Living in a community must begin with mutual understanding to ensure a society who cares for each other is created. Tafahum is an important element in creating a harmonious and prosperous societal life of various ethnicities, races, and religions. When society lives in mutual understanding, all prejudice and misgivings in societal life can be avoided. Those whom have mutual understanding will be more respectful towards the basics of religion and culture lifestyles of the racial melting pot that is Malaysia. Other than that, they will also be more responsible towards the nation and will be able to advice each other in heterogeneous living so that strife, enmity, and conflict between races can be avoided.

Interracial association between the Muslim society and the non-Muslims must have tolerance and maintain good manners. For example, a neighbourhood with different races should be respectful of the racial and cultural differences such as when holding cultural celebrations or weddings. Other than that, a neighbourly life with different races should also be mindful of good interactions and communications such as when visiting the ill. Therefore, the element of mutual understanding within the community together with a firm grasp on religious teachings and maintaining good values is vital in the effort for national unity and harmony within the community (Norafifah, 2014).

\section{Mutual guarantee (Tadhamun)}

The element of guarantee within the community will create feelings of responsibility within one's self to help each other without taking into account religion, race, and ethnicity. For example a Muslim community will help other communities by paying their zakat, giving alms, wakaf, and nafkah among others. All these are done as a role in mutual guarantee to those who are more in need. At an individual level, they would become better citizens; at a familial level, they would be able to maintain a good relationship with their parents and family. At a societal level, they would be able to foster good relationships within the multicultural society. 


\section{Fraternity bond (Ukhwah)}

A fraternity bond or ukhwah in Islam encompasses every member of the community. Humankind was created to love and care for one another, giving rise to a strong fraternity bond. The strength of this bond within the community is a spiritual bond that can create within oneself feelings of compassion, love, care, and respect for self and others. Neighbourly spirits nurtured for example are pride and care for the surrounding community, getting to know one another, and to help out as a community.

In Islam, the Islamic bond of creed, faith, and takwa are key in creating a nation that is consistently united. Therefore in the context of different ethnicities, race, and religion, a strong Muslim brotherhood bond is crucial in maintaining and guaranteeing harmony and economic, political and social stability (Norafifiah, 2014). A fraternity bond is not bound by those whom are of the same religion and race but all crossing the barriers of religion, race, descent, skin colour, and ethnicities among others. This condition will then influence the nonMuslim community to also practice the fraternity bond shown by the Muslims. They will then feel safer and protected as well as equally treated within the society, making this matter an important aspect in humanity values.

\section{Islamic Principles on Humanity Values in Ethnic Diversity in Malaysia Freedom}

The freedom principle in Islam prohibits coercion, insults, slavery, and religious freedom. Every member of society should accept the fact that Allah created humans whom inhabit the face of the Earth with diverse backgrounds, skin colours, languages, religions, tastes, and attitudes. According to Islamic perspective, all these existing differences can be combined and harmonized by creating piety for Allah S.W.T as the Creator. Islam also stands for respecting the privacy of others. A decree by Allah S.W.T states:

O believers! Do not let some 'men' ridicule others, they may be better than them, nor let 'some' women ridicule other women, they may be better than them. Do not defame one another, nor call each other by offensive nicknames. How evil it is to act rebelliously after having faith! And whoever does not repent, it is they who are the 'true' wrongdoers.

(Al-Hujurat: 11)

Islam also celebrates the differences of other cultures but are still staunch on its own Islamic teaching principles. For example, Islam does not determine clothing fashion and it is instead dependent on the weather and the taste of each race, but Islam determined the baseline principles of the fashion wear such as it must cover the aurat with specific limitations for men and women. Islam also gives the freedom to all races in managing their personal lives by using the set principles as a guideline. A decree by Allah S.W.T states:

"For you is your religion, and for me is my religion."

\section{Accord}

(Al-Kafirun: 6)

The principle of accord is something constantly seen in the ruling and governing of a nation. In Malaysia, the non-Muslim community must respect Islam as religion of the Federation of Malaysia, the position of the Kings, the special Malay rights, and the position of Bahasa Melayu as the official language of the nation. This treaty begun since the social contract that 
was drawn up for Malay in achieving independence from the British on $31^{\text {st }}$ August 1957. After Malaysia gained independence, the people of Malaysia were responsible to defend their own peace and harmony by playing a role in continually practicing accord within the community to prevent any acts of disorder, provocation, violence, and others which may in turn cause conflict, riots, and unrest in the country. This accord principle is vital as Malaysia is a country of different races and religions, therefore there is the potential for a multitude of sensitive issues within the community. Therefore, members of the society should understand their own roles in the harmonious unification of the Malaysian nations based on the good values taught by their respective religion, culture, and race.

\section{Justice}

Some examples of the justice principle as enforced in Islam include sentencing, distribution of wealth, and education among others. In a multicultural country such as Malaysia, the rights of the non-Muslims are still fairly defended and protected by the Malaysian Constitution. They have enjoyed rights as recorded in the Federal Constitution and these rights are also in line with the rights given to non-Muslims by Islam. These rights, such as the freedom to embrace and practice any religion in safely and in peace, freedom to erect a house of worship, freedom to eat, drink and dress according to their own culture, freedom to search for livelihood, freedom to own and manage wealth, freedom to choose own leaders, education and health rights, a guarantee for a safe life, freedom for justice in terms of the law, and so forth.

\section{Conclusion}

Humanity values are an important aspect in forming attitude and character within a person. Humanity values are supported by attributes such as affection, charity, love of truth and peace, soft spoken, and others. These humanity values can be integrated to retain good relations among humankind without accounting for race, religion, and culture within the community. When facing the wave of modernization, there is an attitude and character shift to those whom accept the technological innovations brought on by the expansion of the Industrial Revolution 4.0. Following that, the efforts to strengthen these humanity values in the multi-ethnic culture that is Malaysia should be done by taking into account Islamic values in line with the evolution of the Industrial Revolution 4.0. Technological advancement and the integration of Islamic humanity values in Malaysia must be in line and should not be abandoned to ensure ethnic harmony. Awareness among the multi-ethnic community is important to create a nation that is not only technologically advanced, but also the advancement of the nation itself whereby these are both the key ingredients to the advancement of human civilization.

\section{References}

Abdul Khalil, A., Othman, M. K., \& Saidon, M. K. (2020). Memacu Pendidikan di Era Revolusi Industri 4.0: Penerapan Nilai-nilai Islam dan Inovasi dalam Pengajaran di Institusi Pengajian Tinggi. Islamiyyat (Isu Khas) 42: 13 - 20

Burange, A. W., \& Misalkar, H. D. (2015). Review of Internet of Things in development of smart cities with data management \& privacy. International Conference on Advances in Computer Engineering and Applications, Ghaziabad, 2015: 189-195.

Haas, B. (2017). China Bans Religious Names for Muslim Babies in Xinjiang. The Guardian, (April 24, 2017) World news. Retrieved from https://www.theguardian.com/ 
world/2017/apr/25/china-bans-religious-namesfor-muslims-babies-in-xinjiang August 2020).

Hermann, M., Pentek, T., \& Otto, B. (2016). Design principles for industrie 4.0 scenarios. In System Sciences (HICSS). 2016 49th Hawaii International Conference on: 3928-3937.

Keoh, S., Kumar, S., and Tschofenig, H. (2014). Securing the Internet of Things: a standardization perspective. IEEE Internet of Things Journal. 1(3): 265-275.

Kim, J., \& Heo, W. (2018). A Study on Issues and Tasks of Humanity and Social Science in a Fourth Industrial Revolution Era. Journal of Digital Convergence, 16(11): 137-147.

Norafifah, A. H. (2014). Prinsip Islam Dan Nilai-humanity values. (DIm.) Mohd Faizal P. Rameli (ed.). Islam \& Hubungan Etnik: Sorotan Sejarah \& Isu Kontemporari Di Malaysia. Melaka: Academy of Contemporary Islamic Studies, UiTM Melaka.

Pratama, D. A. N. (2019). Tantangan Karakter Di Era Revolusi Industri 4.0 Dalam Membentuk Kepribadian Muslim. Al-Tanzim: Jurnal Manajemen Pendidikan Islam, 3(1): 198-226.

Schwab, K. (2016). The Forth Industrial Revolution. World Economic Forum, 2016. Geneva.

Baharuddin, S. A. (2012). Modul hubungan etnik. Bangi, Selangor: Institut Kajian Etnik, Universiti Kebangsaan Malaysia (UKM).

Vaidyaa, S., Ambadb, P., \& Bhoslec, S. (2018). Industry 4.0 - A Glimpse. 2nd International Conference on Materials Manufacturing and Design Engineering, 20: 233-238.

Van Badham. (2017). We can beat the robot, with democracy. The Guardian. Retrieved from, https://www.theguardian.com/commentisfree/2017/nov/03/we-can-beat-the-robotswithdemocracy (11 August 2020).

Vitz, P. C. (2016). The Role of the Family in the Transmission of the Moral Life. Journal of Law, Philosophy and Culture, 3(1): 181-198.

Wang, W., \& Siau, K. (2019). Artificial Intelligence, Machine Learning, Automation, Robotics, Future of Work and Future of Humanity: A Review and Research Agenda. Journal of Database Management (JDM), 30(1): 61-79.

Wood, J., Nguyen, T., Sharda, S., \& Schlosser, A. (2017). ASEAN 4.0: What does the Fourth Industrial Revolution mean for regional economic integration? White paper: World Economic Forum and the Asian Development Bank (ADB). 